to manufactures-or whether the individual be left to the operation of patent law, it is difficult to conceive of an inquiry of more urgency or importance than one which would enter fully into the merits of the various systems which have not only been found successful in practice, but have also failed to pass the preliminary stage of suggestion. A report from a competent authority would be of the greatest benefit and would repay many times the expense and trouble involved in its preparation. The Committee of the Privy Council for Scientific and Industrial Research has the means within its power, and it is earnestly to be hoped that it may see fit to advise men of science, academic bodies, and commercial syndicates as to the best procedure for the encouragement of scientific investigation and the application of results to daily needs.

\section{PRECIOUS STONES AND PLATINUM IN I9I6.}

TO the twenty-fifth volume of "The Mineral Industry," which deals with the conditions obtaining in the year I916, Dr. G. F. Kunz, the well-known gem expert, contributes not only, as for many years past, the chapter on precious stones, but also another on that most precious of metals, platinum. ${ }^{1}$ In passing we may remark that the scope of this annual publication is not so wide as its title would indicate, the subject being considered entirely from the point of view of the United States.

There is no better or surer indicator of the state of the trade of a country than the business done in jewels. It is not, therefore, surprising to learn that the imports of precious stones into the United States during the year under review reached the remarkable total of ten million pounds sterling, this amount being nearly double that of the preceding year, and exceeding by more than one-tenth the figures for what was at the time considered the exceptionally prosperous year I9r3. About two-thirds of the chapter on precious stones is taken up with the precious stone par excellence-the diamond. During the year the diamond trade with the United States was very much interfered with by the operations of German submarines, more, however, on account of the considerable rise in the rates of insurance than because of the actual losses suffered. At the beginning of the year the Diamond Syndicate raised the price of rough stones by another 5 per cent. This powerful organisation has secured complete control of the diamond market by acting as agents for the sale of the produce of the Premier mine, and by arranging with the Government of the Union of South Africa to purchase the stones found on the sands of the shore of what was once known as German South-west Africa. We are reminded that diamonds, besides their ornamental use, play an important part in in-

\footnotetext{
" 1 (I) "The Production of Precious Stones for the Year 19r6." (2) "Platinum for the Year r916." (New York: McGraw-Hill Book Company, Inc. ; London : Hill Publishing Co., Ltd., rgr 7.$)$
} NO. $252 \mathrm{I}$, VOL. IOO] dustry, and especially the manufacture of munitions of war, by the fact that in November, r916 -none too soon-the British Government placed diamonds suitable for industrial purposes with emery, corundum, carborundum, and all other abrasive materials, whether natural or artificial, on the list of absolute contraband.

Inasmuch as practically all the diamonds placed on the market pass through London, it may appear strange, except to those acquainted with the formerly rigid restrictions of the powerful diamond-cutters' union, that diamond-cutting should have so long languished in this country. The upheaval caused by the war has brought about a change in this respect. Most of the Belgian cutters fled from Belgium on the fall of Antwerp, and many of them came to England. With their aid a number of factories have been started in London, and particularly in Birmingham. Amsterdam, too, benefited by the ruin of the diamond industry of Antwerp, but owing to the shortage of coal a large number of the small factories there were closed by a committee of the trade, and the business was concentrated in the large establishments.

The improved demand for diamonds brought about a revival of business in the South African fields, and the alluvial deposits were very active; the De Beers Company raised very little blue ground, the stones recovered coming almost entirely from ground already on the floors. A 37 -carat stone was found in the recently opened Kameeltontein digging, the stones from which have the peculiar opalescence characteristic of those occurring in the Premier mine. Dr. Kunz points out how little India, once the sole source of diamonds, now contributes to the world's supply. It is thought possible that the deepseated deposits have never been touched; the problem is attracting some attention, but whether prospecting on a suitable scale would prove commercially profitable is under present conditions more than doubtful.

A few interesting points may be gleaned from the remaining pages of this chapter. A large, though imperfectly formed, trapezohedron of garnet, weighing $4.763 \mathrm{~kg}$. (10 $\frac{1}{2} \mathrm{lb}$.), was discovered in the course of grading a property in New York in I9I5. Rubies, to judge from the experience of the Burma ruby mines, are slowly recovering from the depression under which they have for some years laboured, a depression largely caused by the success that has attended the artificial manufacture of this stone. The demand for sapphires continues steady. The Queensland output was formerly wholly in German hands, and for some two years after the outbreak of war operations were brought to a standstill; but an opening has now been obtained on the London market. It is interesting to note that recent experiments have shown that the transparency of the Queensland stones is much improved if they are subjected to a high temperature.

The extraordinary rise in the value of platinum is a striking instance of what happens when an 
enhanced demand is coupled with a restricted supply in an uncontrolled market. Owing to the effects of the war the Russian output, which is normally about 95 per cent. of the world's supply, was reduced to about one-quarter, and at the same time platinum was in greatly increased demand for various purposes arising out of the war, such as the contact-process for producing strong sulphuric acid, aeroplane engines, etc. The result has been that the price of refined platinum in New York rose to more than $20 l$ : the troy oz.-i.e. five times the value of gold weight for weight. Both the high price and the difficulty of obtaining supplies have led to the introduction of various substitutes, such as "palau," a gold-iridium alloy, which has proved very effective for laboratory use; "rhotanium," a gold-palladium alloy, which is satisfactory for all chemical purposes except for use with hot concentrated nitric acid or as electrolytic anodes, and is even better than platinum as a setting for jewels; and "amaloy," an alloy of nickel, chromium, tungsten, etc., which is highly resistant to acid and atmospheric corrosion, and very serviceable in dental work and for surgical instruments. Tungsten appears to have displaced platinum as the material for the targets of X-ray tubes.

\section{PROF. G. A. LEBOUR.}

BY the death, on February 7 , of Prof. Lebour, the scientific world loses a prominent and interesting figure. Born in 1847 and educated at the Royal School of Mines, he served from 1867 to $x 873$ on the Geological Survey. He was lecturer in geological surveying at the University of Durham College of Science (later, Armstrong College) in Newcastle from 1873 to 1879 , and succeeded Page as professor of geology in that institution. This position he occupied until his death, so that for forty-five years he was connected with the college, and for thirty-nine years occupied the chair of geology. In 1904 he received the Murchison medal of the Geological Society, and in the same year was elected vice-principal of Armstrong College.

The transference of heat through the crust of the earth occupied Lebour's attention early and led to measurements of underground temperature in northern coal-pits, and also, in conjunction with Herschel, to the determination of the thermal conductivities of a great number of rocks. This work, issued in a series of B.A. reports from 1873 to I88I, is well known, and many of the data obtained are accepted as standard.

Lebour's name will always be associated with the geology of Northumberland and Durham. Besides his official maps, he brought out in 1877 an excellent geological map of the county of Northumberland, which is the embodiment of much strenuous, clear-sighted labour. He was joint author with Topley of a widely quoted paper on the Great Whin Sill, which may be said to have definitely established its intrusive character. The stratigraphical relations of the carboniferous NO. $252 \mathrm{I}$, VOL. IOO] rocks form the subject of many papers, in which the divisions of the system and the description and correlation of the important limestones, etc., are set forth with admirable lucidity. The economic aspects of the subject find expression in papers on the Redesdale Ironstones and the coals of the Bernician series, especially those associated with the Little Limestone. The future importance of these coals, which occur in rocks below the coal measures proper, is strongly insisted upon, and the lapse of forty years has but added strength to the views then brought forward. Of many papers relating to the geology of Durham may be noted those dealing with the classification of the salt-measures, the breccia-filled fissures in the magnesian limestone (aptly termed by him breccia-gastes), and the marl slate and yellow sands.

Lebour wrote one book, the "Handbook to the Geology and Natural History of Northumberland and Durham," of which three editions have appeared (1878-r889). It is a very effective monument to his life-work in the two counties, and has the remarkable merit of increasing in value the more it is used.

This brief narration of work accomplished gives, however, no true estimate of Lebour's scientific activity and influence. He was a many-sided man, of wonderful fluency, both in the written and spoken word, and a born teacher. His papers are models of clearness and skilful arrangement of material; they are written in flawless English, and they often display that sense of humour which was one of his notable characteristics. These same qualities were, if possible, accentuated in his lectures. He inspired a great band of workers, who have carried his methods and enthusiasm to the four quarters of the globe, and he was ever ready to help, by his sage advice, those whose steps he had directed towards scientific paths. J. A. S.

\section{DR. JOHN MCCRAE.}

T. HE death of Lt.-Col. John McCrae at the early age of forty-four is a sad loss to the Canadian Army Medical Corps and to the profession at large. Dr. McCrae belonged to the type of modern physician in whom the study of disease is based on a thorough training in biology. A pupil of Ramsay Wright and of A. B. Macallum at the University of Toronto, he began his academic career as fellow in biology, and afterwards went to McGill as fellow in pathology. Associated with Prof. Adami at the Royal Victoria Hospital, Montreal, he became known as a popular teacher and a keen investigator of problems in clinical medicine. He was the joint author with Dr. Adami of the well-known "Text-book of Pathology." Always keenly interested in military matters, he joined his old battery at the outbreak of the Boer War, and in I9O2 gained his majority and was given command. It is to be hoped that the valuable notes and sketches of his South African campaigns may be published. In the present war he served with the Canadian Artillery, 